\title{
PENGGUNAAN MODEL PEMBELAJARAN PEER TEACHING DALAM PENGAJARAN TENSES PADA MAHASISWA EFL
}

\author{
Erna Megawati \\ Program Studi Pendidikan Bahasa Indonesia, \\ Fakultas Bahasa dan Seni, Universitas Indraprasta PGRI \\ megawatie45@yahoo.com
}

\begin{abstract}
Abstrak
Penguasaan bahasa Inggris sebagai lingua franca merupakan suatu keharusan, terutama bagi para mahasiswa sebagai agen perubahan. Pembelajaran bahasa Inggris masih menjadi momok bagi mahasiswa Indonesia karena bahasa Inggris masih merupakan bahasa asing (EFL) di Indonesia. Penggunaan model pembelajaran yang tepat akan sangat membantu dalam proses pembelajaran bahasa Inggris, terutama tenses. Model pembelajaran peer teaching menjadi salah satu pilihan dalam pengajaran tenses di universitas. Sample penelitian ini terdiri dari 30 mahasiswa EFL. Tujuan penelitian ini adalah untuk melihat efektifitas dari penggunaan model pembelajaran peer teaching terhadap pengajaran tenses. Penelitian ini menggunakan model penelitian pre-experimental dengan desain one group pretest-posttest design. Hasil penelitian menunjukkan Uji U sebesar 0,309 atau probabilitas di atas 0,05 $(0,309>0,05)$ maka $\mathrm{H}_{0}$ diterima atau skor mahasiswa setelah diberi tindakan dengan model pembelajaran peer teaching tidak berbeda dengan skor sebelum mahasiswa diberikan perlakuan
\end{abstract}

Kata Kunci: Peer teaching, tenses dan Mahasiswa EFL.

\begin{abstract}
English mastery as lingua franca has become a necessity, especially for undergraduate students as the agent of changes. English learning still considered as a constraint among Indonesian students since English is still foreign in Indonesia. The usage of appropriate model of learning believed to help in English learning, especially tenses. Peer teaching has become a choice in tenses teaching at university. Sample of the research taken from 30 undergraduate students of EFL. The objective of the research is to discover the effectiveness of peer teaching usage in teaching tenses. The model used in the research is pre-experimental design with one group pretest-posttest design. The result of U- test is 0,309 or probability above 0,05 (0,309 > 0,05) therefor $H_{0}$ is accepted, there is no significant before and after given treatment of peer teaching model.
\end{abstract}

Keywords: Peer teaching, tenses, EFL Student

\section{PENDAHULUAN}

Bahasa merupakan alat komunikasi bagi manusia. Melalui bahasa, manusia bisa berkomunikasi dengan manusia lainnya dan menyampaikan maksud serta keinginan hatinya. Pada saat ini bahasa Inggris ditetapkan menjadi lingua franca, yaitu digunakan oleh berbagai bangsa yang tidak mempunyai bahasa ibu.

Seiring dengan gemuruhnya revolusi teknologi 4.0 maka keterampilan bahasa Inggris menjadi hal yang tidak bisa ditawar-tawar lagi. Bahasa Inggris juga menjadi salah satu mata kuliah dasar umum yang harus diampu bagi mahasiswa program studi 
Pendidikan Bahasa Indonesia. Salah satu kesulitan atau momok dalam mata pelajaran bahasa Inggris sebagian berasal dari tenses. Salah satu faktor penentu dalam pembelajaran tenses adalah penggunaan model pembelajaran yang tepat. Peneliti menduga bahwa model peer teaching mrupakan solusi atas kesulitan dalam mata pelajaran bahasa Inggris. Mengingat pentingnya Bahasa Inggris sebagai lingua franca dan dalam rangka pasar bebas maka perlu dilakukan berbagai upaya untuk meningkatkan hasil pembelajaran Bahasa Inggris. Berdasarkan alasan tersebut maka peneliti hendak melakukan penelitian efektivitas model peer teaching alam Pembelajaran Tenses Mahasiswa Bahasa Indonesia di Perguruan Tinggi Swasta, Jakarta Timur.

Berdasarkan latar belakang di atas, maka masalah yang akan diteliti dirumuskan menjadi "Bagaimanakah efektivitas model peer teaching alam Pembelajaran Tenses Mahasiswa Bahasa Indonesia di Perguruan Tinggi Swasta, Jakarta Timur?". Adapun tujuan dari penelitian ini untuk mengetahui tingkat efektivitas model peer teaching alam Pembelajaran Tenses Mahasiswa Bahasa Indonesia di Perguruan Tinggi Swasta, Jakarta Timur. Hasil penelitian ini diharapkan dapat memberikan kontribusi bermanfaat baik secara teoretis maupun praktis. Secara teoretis, penelitian ini dapat menambah pengetahuan dan keterampilan peneliti mengenai penggunaan metode pembelajaran Peer teaching. Manfaat selanjutnya, diharapkan dapat meningkatkan kualitas pengajaran bahasa Inggris pada peserta didik.

Pada tinjauan pustaka ini akan diurai teori-teori relevan terkait penelitian yang akan dilaksanakan.

\section{Metode Peer Teaching}

Metode tutor sebaya dilakukan dengan cara memberdayakan kemampuan siswa yang memiliki daya serap tinggi, siswa tersebut mengajarkan materi kepada temantemannya yang belum paham, sehingga memenuhi ketuntasan belajar semuanya. Metode tutor sebaya merupakan suatu metode yang mengintegrasikan antara ide tentang ketuntasan belajar (Mastery Learning) dan penggunaan penguatan (reinforcement).

Howe (Harper \& Maheady, 2007) menjelaskan bahwa, "Peer teaching strategies, especially classwide models, are not value free. These models emphasize an equality in opportunity, mutual assistance, shared goals, interdependency, and group cohesion.' Strategi peer teaching, terutama dalam model pembelajaran kelas dalam jumlah banyak tidaklah bebas nilai. Model tersebut menekankan pada kesamaan dalam kesempatan, saling membantu, berbagi tujuan, saling bekerja sama dan kohesi kelompok.

Vasay (Vasay, 2010) dalam penelitiannya The effects of peer teaching in the performance of students in mathematics menyatakan bahwa 'peer teaching is a technique in helping students perform better in understanding the different concepts, developing computational skills and their moral, social and emotional values most especially teir ability to express ideas.' Dalam pandangan Vasal, model pembelajaran peer teaching merupakan sebuah teknik yang dapat membantu peserta didik untuk memahami berbagai konsep berbeda, mengembangkan kemampuan komputasi dan nilai-nilai moral, sosial dan emosi terutama kemampuan mereka dalam mengungkapkan ide. Dari penelitian tersebut ditemukan bahwa ada perbedaan yang signifikan kondisi tidak menggunakan model pembelajaran peer 
teaching dengan yang menggunakan model pembelajaran peer teaching.

Boud (Boud, Cohen, \& Sampson, 1999) mendefinisikan 'peer learning refers to the use of teaching and learning strategies in which students learn with and from each other without the immediate intervention of a teacher.' Model pembelajaran tutor sebaya mengacu kepada penggunaan strategi pengajaran dan pembelajaran di mana peserta didik saling belajar satu sama lain tanpa interfensi seorang guru.

Graham (Rees, Quinn, Davies, \& Fotheringham, 2016) menjelaskan jika model pembelajaran peer teaching memberikan kesempatan bagi tutor untuk memperoleh pengetahuan dan keterampilan baru. Hal tersebut dimungkinkan karena dengan mengajar, para tutor mengaplikasikan pengetahuannya ke dalam kenyataan sehingga akan memperdalam wawasan tutor itu sendiri. Rees, Quinn, Davies dan Fotheringham (Rees et al., 2016) dalam penelitiannya How does peer teching compare faculty teaching? A systematic review and meta-analysis menemukan bahwa tidak ada perbedaan signifikan antara hasil dari model pembelajaran peer teaching dengan faculty teaching.

Lockspeiser (Rees et al., 2016) menjelaskan bahwa kunci pada model pemebelajaran peer teaching adalah elemen kesamaan kognitif dan sosial. Dimaksud dengan kesamaan kognitif adalah terbangunnya kesamaan intelektual dan proses pemikiran dari tutor dan pelajar. Keduanya diyakini berpeluang mencapai tahap kesamaan kognitif lebih besar ketimbang model konvensional. Pada model ini, para tutor dituntut untuk dapat meyampaikan materi kompleks dengan cara yang dapat dipahami oleh peserta didik lainnya.
Pendapat Edward L. Dejnozken dan David E. Kopel dalam American Education Encyclopedia dikutip Yopi Nisa.F (dalam jurnal edunomic; 2014) bahwa tutor sebaya adalah sebuah prosedur siswa mengajar siswa lainnya. Tipe pertama adalah pengajar usiayang sama. Tipe kedua adalah pengajar yang lebih tua usianya dari pembelajar. Tipe yang lain kadang dimunculkan pertukaran usia pengajar.

Evans (Evans \& Cuffe, 2009) menjelaskan bahwa model pembelajaran peer teaching sebagai pendekatan pembelajaran yang bernilai dan efektif yang telah diterapkan pada berbagai pendekatan seperti medis, kedokteran gigi dan berbagai mata kuliah kesehatan. Hal tersebut dimungkinkan karena model pembelajaran peer teaching membangun satu lingkungan belajar yang memungkinkan para peserta didik merasa nyaman untuk mengungkapkan berbagai kesulitan dalam proses pembelajaran. Dalam penelitiannya, Near-peer teaching in anatomy: An approach for deeper learning, menunjukkan bila persepsi pelajar tahun pertama dan kedua terhadap tutor adalah posistif. Mereka menemui bahwa tingkat pengetahuan para tutor sangat mumpuni dalam berbagai kasus.

Bayu Mukti (2009) mengemukakan bahwa tutor sebaya adalah suatu pembelajaran di mana murid dan guru adalah teman sebaya yang bertujuan memberikan bimbingan kepada siswa lain agar bisa mencapai hasil yang maksimal.

Menurut Sawali (2009), langkah-langkah metode tutor sebaya adalah sebagai berikut:

1. Pilih materi yang memungkinkan materi tersebut dapat dipelajari siswa secara mandiri;

2. Bagilah para siswa menjadi kelompok-kelompok kecil yang 
heterogen. Siswa-siswa pandai disebar dalam setiap kelompok dan bertindak sebagai tutor sebaya, atau disebut "mentor";

3. Masing-masing kelompok diberi tugas mempelajari satu sub materil kompetensi dasar. Setiap kelompok dibantu oleh siswa yang pandai sebagai tutor sebaya.

4. Beri mereka waktu yang cukup untuk Untuk menentukan siapa yang akan menjadi tutor, diperlukan pertimbangan tersendiri Seorang tutor belum tentu siswa yang paling pandai, yang penting diperhatikan siapa yang menjadi tutor tersebut.

Menurut Djamarah dan Zain (2002), ada beberapa hal yang harus diperhatikan dalam memilih siapa yang menjadi tutor sebaya, yaitu:

1. dapat diterima (disetujui) oleh siswa yang mendapat program perbaikan, sehingga siswa tidak mempunyai rasa takut atau enggan untuk bertanya kepadanya.

2. dapat menerangkan bahan belajar yang diperlukan oleh siswa

3. tidak tinggi hati, apa lagi kejam, atau keras hati terhadap sesama kawan;

4. mempunyai daya kreatifitas yang cukup untuk memberikan bimbingan, yaitu dapat menerangkan pelajaran kepada kawannya.

Untuk memperoleh siswa yang memenuhi berbagai persyaratan tersebut di atas memang sulit. Akan tetapi, hal ini dapat diatasi dengan jalan memberikan petunjuk sejelas-jelasnya tentang apa yang harus dilakukan. Petunjuk ini memang mutlak diperlukan bagi setiap tutor, karena hanya gurulah yang mengetahui jenis kelemahan siswa, sedangkan tutor hanya membantu temannya, bukan mendiagnosis.
Seperti halnya metode pembelajaran yang lain, tutor sebaya juga mempunyai kelebihan dan kekurangan. Kelebihan tutor sebaya antara lain:

1. Siswa menjadi mandiri karena mereka bisa menentukan sendiri teknik penyampain yang digunakan dalam menyampaikan bahan pelajaran.

2. Siswa menjadi tidak egois dan mempunyai rasa setia yang tinggi karena siswa yang pandai dididik menjadi anak yang mau berbagi dan mau membantu temannya.

3. Siswa menjadi lebih leluasa karena bisa bertanya kepada temannya sendiri.

4. Bahan bisa lebih mudah diterima karena menggunakan dalam penyampaian menggunakan bahasa yang mereka mengerti.

5. Siswa yang menjadi tutor mendapat keuntungan dengan mempunyai pengalaman mengajar.

Selain kelebihan tutor sebaya juga mempunyai kekurangan. Kekurang tersebut dapat diminimalisir dengan jalan melatih tutor untuk mengajar berdasarkan silabus yang ditentukan sehingga tujuan pembimbingan dapat tercapai.

Berdasarkan berbagai penelitian relevan di atas maka peneliti hendak meneliti efektivitas model pembelajaran peer teaching pada pengajaran tenses yang dilakukan pada mahasiswa EFL di sebuah Perguruan Tinggi swasta di Jakarta Timur.

\section{Hakikat Pembelajaran}

Dalam UU RI No. 20 Tahun

2003 tentang Sistem Pendidikan Nasional, pendidikan adalah usaha sadar dan terencana untuk mewuudkan Suasana belajar dan dan proses pembelajaran agar peserta didik secara 
efektif mengembangkan potensi dirinya untuk memiliki kekuatan spiritual keagamaan, pengendalian diri, kepribadian, kecerdasan, akhlak mulia, serta keterampilan yang dibutuhkan dirinya, masyarakat, bangsa dan negara. Pendidikan juga merupakan pembelajaran, pengetahuan, keterampilan, dan kebiasaan sekelompok orang yang diturunkan dari satu generasi ke generasi berikutnya melalui pengajaran, pelatihan, atau penelitian. Pendidikan berfungsi untuk memelihara atau meneruskan pengetahuan, ide-ide atau nilai-nilai ke generasi berikutnya (sukmadinata, 2009). Ide-ide tersebut dituang dalam bentuk aksara.

$$
\text { Pembelajaran diidentikkan }
$$
dengan kata "mengajar" berasal dari kata dasar "ajar" yang berarti petunjuk yang diberikan kepada orang supaya diketahui (diturut) ditambah dengan awalan "pe" dan akhiran "an menjadi "pembelajaran", yang berarti proses, perbuatan, cara mengajar atau mengajarkan sehingga anak didik mau belajar (KBBI).

Dengan demikian, menjadi jelas bahwa pembelajaran merupakan suatu usaha yang sengaja yang dilakukan secara sistemik dan berisi konsep yang akan digunakan untuk membantu proses belajar siswa.

\section{Metode Pembelajaran Bahasa Inggris}

Tiap-tiap pelajaran mempunyai metode atau cara pengajaran tersendiri, demikian pula dalam pembelajaran bahasa Inggris. Bahasa Inggris merupakan alat untuk berkomunikasi secara lisan dan tulisan. Berkomunikasi berarti memahami dan mengungkapkan informasi, pikiran perasaan, serta mengembangkan ilmu pengetahuan, teknologi, dan upaya dengan menggunakan bahasa tersebut (Standar
Kompetensi Mata Pelajaran Bahasa Inggris, 2003).

a. Pengertian bahasa Inggris

Bahasa memiliki peran sentral dalam perkembangan intelektual, sosial, dan emosional siswa dan merupakan kunci penentu menuju keberhasilan dalam mempelajari semua bidang studi. Bahasa diharapkan membantu siswa mengenal dirinya, budayanya, dan budaya orang lain, mengemukakan gagasan dan perasaan, berpartisipasi dalam masyarakat yang menggunakan bahasa tersebut, membuat keputusan yang bertanggung jawab pada tingkat pribadi dan sosial, menemukan serta menggunakan kemampuankemampuan analisis dan imaginatif yang ada dalam dirinya.

Bahasa Inggris merupakan alat untuk berkomunikasi secara lisan dan tulisan. Pengertian berkomunikasi dimaksudkan adalah memahami dan mengungkapkan informasi, pikiran, perasaan, serta mengembangkan ilmu pengetahuan, teknologi, dan budaya dengan menggunakan bahasa tersebut. Kemampuan berkomunikasi dalam pengertian yang utuh adalah kemampuan berwacana.

b. Fungsi dan tujuan

Dalam konteks pendidikan, bahasa Inggris berfungsi sebagai alat untuk berkomunikasi dalam rangka mengakses informasi, data dalam konteks sehari-hari, sebagai alat untuk membina hubungan interpersonal, bertukar informasi serta menikmati estetika bahasa dalam budaya Inggris. Mata pelajaran bahasa Inggris memiliki tujuan sebagai berikut:

1) Mengembangkan kemampuan berkomunikasi dalam bahasa tersebut, dalam bentuk lisan dan 
tulis.

berkomunikasi

Kemampuan meliputi

mendengarkan

(listening),

berbicara (speaking), membaca (reading), dan menulis (writing).

2) Menumbuhkan kesadaran tentang hakikat dan pentingnya bahasa Inggris sebagai salah satu bahasa asing untuk menjadi alat utama belajar.

3) Mengembangkan pemahaman tentang saling keterkaitan antar bahasa dan budaya serta memperluas cakrawala budaya. Demikian siswa memiliki wawasan lintas budaya dan melibatkan diri dalam keragaman budaya.

c. Ruang lingkup

Ruang lingkup mata pelajaran bahasa Inggris meliputi:

1) Ketrampilan berbahasa, yaitu mendengarkan, berbicara, membaca dan menulis.

2) Sub-kompetensi yang meliputi kompetensi tindak bahasa, linguistik (kebahasaan), sosiokultural, strategi dan kompetensi usaha.

3) Pengembangan sikap yang positif terhadap bahasa Inggris sebagai alat komunikasi.

\section{Hakikat Tenses}

Nofriani (Kholiani \& Rosyadi, 2016) menjelaskan bahwa tenses adalah bentuk kata kerja yang berhubungan dengan waktu. Dengan demikian, dengan adanya sistem tenses dalam suatu bahasa maka perubahan waktu akan memengaruhi bentuk kata kerja yang digunakan. Sistem tenses ini tidak berlaku pada bahasa Indonesia sehingga pembelajar bahasa Inggris sebagai bahasa kedua sering mengalami kendala dalam menguasai tenses.

Brown (Verbs and Tenses.pdf, n.d.) mendefinisikan, 'A tense shows the relationship between the time and utterance and the actual time of the action or the state.' Konsep tense menunjukkan hubungan antara waktu dan ujaran dan waktu secara aktual dari sebuah kejadian atau sebuah kondisi. Sebagai contoh:

I drank a cup of tea yesterday.

I am drinking a cup of tea now.

I will drink a cup of tea tomorrow.

I have drunk a cup of tea.

I drink a cup of tea every day

Kalimat pertama menunjukkan hubungan antara waktu dan ujaran dan waktu aktual kejadian. Pada contoh ini, waktu aktual ditunjukkan dengan kata 'yesterday' dan dengan struktur kalimat keseluruhan. Bentuk kata 'drank' adalah bentuk lampau dari kata'drink'. Kalimat kedua menunjukkan bahwa waktu ujaran dan waktu sesungguhnya terjadi pada saat bersamaan. Waktu kejadian ditunjukkan denan kata 'now'. Terkadang, waktu aktual tindakan dapat dipahami di luar konteks sehingga hal yang memungkinkan untuk tidak menggunakan kata yang menunjukkan waktu aktual dari sebuah tindakan atau kondisi. Kalimat ketiga menunjukkan bahawa waktu aktual akan terjadi besok. Hal tersebut ditunjukkan dengan keseluruhan struktur kalimat dan dengan kata 'tomorrow' yang mewakili waktu tindakan dan juga modal 'will'. Kalimat keempat, present perfect, menunjukkan waktu aktual baru saja terjadi pada saat tindakan terjadi. Dengan kata lain, present perfect memberikan ide bahwa satu kejadian terjadi sebelum kejadian laiinya. Hal tersebut ditunjukkan dengan modal 'have'. Kalimat ke lima, simple present tense, menunjukkan waktu aktual kejadian atau keadaan terjadi secara rutin. Hal tersebut ditunjukkan dengan kata 'every day'. Azar (Schrampfer, 202AD) menjelaskan makna dari 
simple present tense ' expresses events or situations that exist always, usually, habitually.' Penggunaan simple present tense adalah untuk menunjukkan kejadian atau situasi terjadi selalu, biasanya dan kebiasaan.

Penelitian tentang tenses sudah banyak dilakukan di antaranya oleh Marit (Julien, 2001) dalam jurnal Linguistic yang berjudul The syntax of complex tenses. Temuan penelitian ini mengungkapkan argument tenses dalam bentuk presents dalam rangka analisis biclausal yang diistilahkan periphrastic tenses.

\section{METODE PENELITIAN}

Penelitian ini dilaksanakan selama 4 (empat) bulan terhitung sejak bulan September--November 2018. Berdasarkan tujuan penelitian yaitu meningkatkan penguasaan tenses bahasa Inggris mahasiswa EFL dengan motode Peer Teaching, maka peneliti menggunakan metode penelitian eksperimen. Beberapa bentuk desain eksperimen yang dapat digunakan dalam penelitian, yaitu preexperimental design, true experimental design, factorial design, dan quasi experimental design Sugiyono (2012: 110). Penelitian ini adalah penelitian pre-experimental design.

Guy (Gay, L.R: Mills, E.G and Airasian, 2012) mendefinisikan, 'Experimental research is the only type of research that can test hypotheses to establish cause-effect relations. It represents the strongest chain of reasoning about the links between variables. ' penelitian eksperimen merupakan satu-satunya jenis penelitian yang dapat digunakan untuk menguji hipotesis yang menunjukkan hubungan sebab akibat. Penelitian ini juga menunjukkan hubungan yang kuat di antara variable penelitian.
Desain variable tunggal dapat digolongkan sebagai pre-experimental design, true experimental design, factorial design, dan quasi experimental design bergantung kepada tingkat pengendalian terhadap ancaman penelitian dan validitas eksternal. Pada pre-experimental design terdapat beberapa desain, yaitu the one-shot case study, the one group pretest posttest design dan static-group comparison.

Dalam penelitian ini, peneliti menggunakan metode eksperimen dengan bentuk desain preexperimental design dengan jenis one group pretestposttest design. Adapun pada jenis penelitian ini akan dilakuan pretest dan posttest terhadap kemampuan peserta didik. Pretest dilakukan sebelum diberikannya treatment atau perlakuan. Selajutnya posttest diberikan setelah treatment atau perlakuan dilakukan. Dengan diberikannya pretest dan posttest hasil dari perlakuan dapat diketahui lebih akurat, karena dapat membandingkan dengan keadaan sebelum diberikan perlakuan.

Variabel adalah segala sesuatu yang akan menjadi objek pengamatan dalam penelitian. Variabel penelitian adalah suatu atribut atau sifat atau nilai dari orang, objek atau kegiatan yang mempunyai variasi tertentu yang di tetapkan oleh peneliti untuk dipelajari dan kemudian di tarik simpulannya. Variable terikat yang diukur adalah penguasaan kosakata bahasa Inggris dalam ruang lingkup kata benda yang ada di sekitar lingkungan peserta didik. Variabel terikat tersebut dikontrol dengan menggunakan pre-test dan posttest dengan menggunakan metode Peer Teaching.

Metode Peer Teaching suatu metode pengajaran bahasa yang dibangun berdasarkan aktivitas-aktifitas dalam kelompok. Peserta didik, dalam hal ini mahasiswa akan merasa lebih 
nyaman dan leluasa untuk membahas kendala pembelajaran karena didampingi oleh teman sebaya yang ditugaskan sebagai tutor kelompok.

Berikut ini desain one group pretest-posttest design:

\section{$\mathrm{O} 1 \mathrm{X} \mathrm{O}^{2}$}

$\mathrm{O} 1=$ pretest

$\mathrm{X}=$ perlakuan yang diberikan

$\mathrm{O} 2=$ posttest

Dalam pelaksanaan penelitian ini, peneliti menggunakan prosedur sebagai berikut:

1. Kenakan O1, yaitu pretest untuk mengukur kemampuan awal tenses mahasiswa sebelum diberi model pembelajaran.

2. Kenapa subjek, $X$, satu perlakukan sebagai penerapan model pembelajaran Peer Teaching.

3. Berikan $\mathrm{O} 2$, yaitu posttest untuk mengukur kemampuan tenses mahasiswa setelah diberikan perlakuan yaitu model pembelajaran peer teaching.

4. Kemudian bandingkan antara $\mathrm{O} 1$ dengan $\mathrm{O} 2$ untuk mengetahui perbedaan antara sebelum dengan sesudah diberikan perlakuan.

Populasi dalam penelitian ini adalah seluruh mahasiswa semester pertama di universitas swasta Jakarta Timur yang terdiri dari 5 kelas paralel. Peneliti memilih sampel dengan nonrandom sampling dengan purposive sampling. Gay (Gay, L.R: Mills, E.G and Airasian, 2012) menjelaskan bahwa non-random sampling adalah proses pemilihan sebuah sample menggunakan Teknik yang tidak memungkinkan peneliti untuk menspesifikasi kemungkinan atau kesempatan yang dimiliki oleh anggota populasi yang telah dipilih. Metode ini tidak menggunakan metode acak pada tiap tahapannya. Salah satu jenis nonrandom sampling adalah purposive sampling. Purposive sampling atau judgement sampling adalah proses pemilihan sample yang diyakini dapat mewakili populasi. Dengan kata lain, peneliti memilih sample berdasarkan pengalaman dan pengetahuan terhadap grup yang akan dijadikan sample. Pengetahuan ini menjadi panduan dalam memilih sample sesuai kriteria. Sample pada penelitian ini adalah kelas Regular 1 C yang terdiri dari 30 mahasiswa.

Teknik untuk mengumpulkan data dalam penelitian ini adalah tes. Suharsimi (2005:100) mengatakan tes adalah pengumpulan kumpulan beberapa pertanyaan atau alat lain yang digunakan untuk mengukur keterampilan, pengetahuan IQ, kemampuan atau bakat yang dimiliki oleh individu atau kelompok. Tes yang diberikan kepada anak, dalam bentuk tes lisan dan perbuatan. Anak diminta menyebutkan kosakata kata benda dalam bahasa Inggris dan menunjukkan benda yang diucapkan dengan bahasa Inggris.

Penggunaan kriteria penilaian dalam penelitian ini berdasarkan dikemukakan Arikunto (1993: 29) sebagai berikut:

a. Skor 1 (satu) bila jawaban peserta didik benar

b. Skor 0 (nol) bila jawaban peserta didik salah

Instrumen yang akan diberikan kepada anak berupa seperangkat tes yang disusun dalam bentuk format indikator yang berisi tenses bahasa Inggris meliputi simple present, simple past tense, present perfect tense, dan present continuous. Untuk menentukkan kelayakan instrument, dilakukan uji validitas dan reabilitas terhadap instrument. Uji coba instrumen dilaksanakan dengan tujuan untuk 
mengetahui tingkat validitas dan reliabilitas instrumen penelitian. Instrumen yang valid berarti "instrumen tersebut dapat digunakan untuk mengukur apa yang seharusnya diukur." (Sugiyono, 2006:173). Instrumen yang reliabel berarti "instrumen yang bila digunakan beberapa kali untuk mengukur objek yang sama, akan mendatangkan data yang sama." (Sugiyono, 2006: 173). Penggunaan instrumen yang valid dan reliabel dalam pengumpulan data, diharapkan akan diperoleh data yang dapat dipercaya kebenarannya.

Instrumen yang digunakan diuji validitasnya dengan menggunakan pendapat dari ahli (judgement experts). Para ahli diminta pendapatnya tentang instrumen yang telah disusun. Para ahli akan memberi keputusan: instrumen dapat digunakan tanpa perbaikan, ada perbaikan, dan mungkin diubah total. Para ahli yang diminta pendapatnya, yaitu dua orang dosen Bahasa Inggris, dan satu orang relawan pengajar kelompok belajar yang memegang subjek penelitian.

Instrumen yang telah disusun harus diujicobakan untuk mengetahui data tersebut sudah reliabel atau belum. Adapun subjek ujicoba instrumen ini tentunya harus memiliki karakteristik sama atau mendekati karakteristik subjek yang sebenarnya. Dalam hal ini subjek tersebut adalah peserta didik kelompok belajar yang memiliki kemampuan kosakata bahasa Inggris yang rendah.

Instrumen yang digunakan diuji reliabilitasnya dengan menggunakan test - retest. Test - retest dilakukan dengan cara mencobakan instrumen beberapa kali kepada subjek penelitian. Dalam hal ini, instrumen yang digunakan sama, subjek yang sama, tetapi waktunya berbeda. Reliabilitas diukur dari koefisien korelasi antara percobaan pertama dan berikutnya. "Bila koefisien korelasi positif dan signifikan maka instrumen tersebut sudah dinyatakan reliabel." (Sugiyono, 2006: 184). Perhitungan koefisien korelasi antara percobaan pertama dan berikutnya yaitu dengan menggunakan rumus korelasi product moment angka kasar.

$$
\mathrm{r}_{\mathrm{xy}}=\frac{\mathrm{N} \cdot \Sigma \mathrm{XY}-(\Sigma \mathrm{X})(\Sigma \mathrm{Y})}{\sqrt{\left\{\left(\mathrm{N} \cdot \Sigma \mathrm{X}^{2}\right)-(\Sigma \mathrm{X})^{2} \cdot\left(\mathrm{N} \cdot \Sigma \mathrm{Y}^{2}\right)-(\Sigma \mathrm{Y})^{2}\right.}}
$$

Keterangan:

rxy $=$ Koefisien korelasi $X$ dan Y

$X=$ Nilai percobaan awal

$\mathrm{Y}=$ Nilai percobaan akhir

$\mathrm{N}=$ Jumlah Subjek

Setelah perhitungan relibialitas diketahui koefisien korelasinya $\mathbf{0 , 3 2}$. Menurut Suharsono kriteria koefisiensi korelasi yang mendekati angka 1 mempunyai korelasi cukup. Dengan demikian instrumen tersebut mempunyai korelasi dan dapat dikatakan reliabel sehingga dapat digunakan dalam penelitian.

Untuk mengolah data hasil penelitian, teknik analisis yang digunakan adalah statistic non parametrik, karena subjek penelitiannya kecil serta distribusi dan variasi populasinya tidak memerlukan uji normalitas. Sidney Siegel (1992:145) menyatakan bahwa statistik non parametrik tidak menguji parameter populasi tetapi menguji distribusi. Statistik non parametrik tidak menuntut banyak asumsi bahwa data yang dianalisis tidak harus berdistribusi normal dan digunakan untuk menganalisis data nominal, ordinal. Uji statistika yang digunakan adalah Uji Mann Whitney (uji U) dengan rumusan menurut Moh. Nazir

(2005: 205) adalah: 


$$
\begin{aligned}
& U_{1}=n_{1} \cdot n_{2}+\frac{n_{2}\left(n_{2}+1\right)}{2}-\sum R_{2} \\
& U_{2}=n_{1} \cdot n_{2}+\frac{n_{1}\left(n_{1}+1\right)}{2}-\sum R_{1}
\end{aligned}
$$

Keterangan:

$\mathrm{U} 1 / \mathrm{U} 2=$ Koefisien $\mathrm{U}$ tes.

$\mathrm{R} 1$ = Rangking/peringkat kelompok pretes.

$\mathrm{R} 2$ = Rangking/peringkat kelompok postes.

$\mathrm{n} 1=$ Jumlah kelompok pretes.

n2 = Jumlah kelompok postes.

Dengan kriteria pengujian

penilaian ini adalah:

$\mathrm{H}_{0}$ diterima jika $\mathrm{U}$ hitung $>\mathrm{U}$ tabel pada taraf signifikan $95 \%$ atau $\geq=0,05$.

Ha diterima jika $\mathrm{U}$ hitung $<\mathrm{U}$ tabel pada taraf signifikan $95 \%$ atau $<=0,05$.

Teknik analisis data yang digunakan dalam penelitian ini dilakukan setelah selesai pengumpulan data. Untuk mengolah data hasil peneltian, teknis analissi yang digunakan adalah statistic non parametrik karena subyek penelitian yang digunakan dalam skala kecil serta distribusi dan variasi populasinya tidak memerlukan uji normalitas. Riadi (2016:181) menjelaskan bahwa uji statistic non-parametrik digunakan untuk mengukur distribusi dan tidak menuntut banyak asumsi bahwa data yang dianalisis tidak harus berdistribusi normal dan dapat digunakan untuk menganalisis data nominal, ordinal. Uji statistic yang digunakan adalah uji Mann whitney (uji U).

\section{HASIL DAN PEMBAHASAN}

Pada bagian ini dipaparkan dan dibahas data yang terkumpul dari hasil penelitian yang meliputi: pengujian hipotesis, hasil penelitian, dan pembahasan. Uji Statistika yang digunakan adalah Uji Mann Whitney (Uji U). riadi (2016: 220) menjelaskan penggunaan uji $U$ adalah dalam ranka membadingkan dua mean independent yang berasal dari populasi yang homogen dan dapat juga digunakan untuk menguji kesamaan dua mean populasi.

\begin{tabular}{|c|c|c|c|}
\hline No & NAMA & Pretest & Postest \\
\hline 1 & Syaeful B & 7 & 11 \\
\hline 2 & Octaviastri & 15 & 14 \\
\hline 3 & Lia R. & 15 & 11 \\
\hline 4 & Andes & 14 & 8 \\
\hline 5 & Ibnu & 9 & 12 \\
\hline 6 & Pascal & 19 & 13 \\
\hline 7 & Anisa & 14 & 15 \\
\hline 8 & Laila & 12 & 11 \\
\hline 9 & Faizah & 11 & 17 \\
\hline 10 & Niken & 15 & 14 \\
\hline 11 & Fahriyah C. & 8 & 16 \\
\hline 12 & Firman & 6 & 4 \\
\hline 13 & Mayang S. & 7 & 9 \\
\hline 14 & Priska P. & 10 & 8 \\
\hline 15 & Akhmad K. & 14 & 10 \\
\hline 16 & Novita S. & 11 & 17 \\
\hline 17 & Atila & 4 & 11 \\
\hline 18 & Rohimah & 18 & 20 \\
\hline 19 & Amanda & 4 & 12 \\
\hline 20 & Olympia R. & 6 & 14 \\
\hline 21 & Margareta & 17 & 18 \\
\hline 22 & Ayu F. & 12 & 15 \\
\hline 23 & Usnul H. & 11 & 10 \\
\hline 24 & robertus & 16 & 17 \\
\hline 25 & Silvia T. & 10 & 10 \\
\hline 26 & Adam & 14 & 14 \\
\hline 27 & Ulfa D & 7 & 10 \\
\hline 28 & Lia A. & 12 & 11 \\
\hline 29 & Rindi A. & 11 & 13 \\
\hline 30 & Rizqi D & 13 & 13 \\
\hline
\end{tabular}

Tabel 2 Data Sampel Pretest dan Posttest

kelas sampel dari hasil pretest dan posttest. Pretest diberikan sebelum kelas sample mendapatkan perlakuan berupa model pembelajaran peer teaching. Kemudian mahasiswa diberikan model pembelajaran peer teaching dengan materi ajarnya berupa tenses: simple present, present perfect tense, simple past tense dan present continuous tense.

Data pretest menunjukkan skor tertinggi adalah 19 sedangkan terendah adalah 4. Skor rata-rata dari pretest adalah 11,4. Pretest dan posttest diberikan pada satu kelas sampel. Pada pemberian Pretest, sample tidak diberikan perlakukan apapun 
sebelumnya. Pretest diberikan untuk mengukur kemampuan awal sampel.

Data posttest menunjukkan skor tertinggi adalah 20, sedangkan terendah adalah 4. Skor rata-rata dari pretest adalah 12,6. Pretest dan posttest diberikan pada satu kelas sampel. Pada pemberian Postest, sample sudah diberikan perlakukan berupa model pembelajaran peer teaching. Postest diberikan untuk mengukur kemampuan sampel setelah diberikan perlakukan untuk kemudian dibandingkan dengan kondisi sebelum diberikan perlakuan. Kemudian, data tersebut dihitung dengan statistic Uji $U$ yang menghasilkan:

Tabel 3 Output Mann-Whitney Test

\begin{tabular}{lllrr}
\hline \multicolumn{4}{c}{ Ranks } \\
\hline \multirow{4}{*}{ NILAI } & METODE & N & Mean Rank & Sum of Ranks \\
1 & 30 & 28.22 & 846.50 \\
2 & 30 & 32.78 & 983.50 \\
Total & 60 & & \\
\hline \multicolumn{4}{c}{ Test Statistics ${ }^{\text {a }}$} \\
\hline \multicolumn{4}{c}{ NILAI } \\
Mann-Whitney U & 381.500 \\
Wilcoxon W & 846.500 \\
Z & -1.017 \\
Asymp. Sig. (2-tailed) & .309 \\
a. Grouping Variable: METODE \\
\hline
\end{tabular}

Analisis Uji Mann-Whitney Test dengan hipotesis sebagai berikut:

1. $\mathrm{H}_{0}$ diterima jika $\mathrm{U}$ hitung >

$\mathrm{U}$ tabel pada taraf signifikan $95 \%$ atau $\geq=0,05$.

2. $\quad \mathrm{H}_{\mathrm{a}}$ diterima jika U hitung < U tabel pada taraf signifikan $95 \%$ atau $<=0,05$.

H0 kedua data sampel dinilai indentik yaitu data pada kedua skor kelompok belajar tidak berbeda secara signifikan, sedangkan $\mathrm{Ha}$ kedua skor kelompok belajar tidak identic yaitu berbeda secara signifikan.

Berdasarkan output SPSS 16 di atas, terlihat bahwa pada kolom
Asym.Sig (2-tailed)I asymptotic significance untuk uji pada dua sisi adalah 0,309 atau probabilitas di atas $0,05(0,309>0,05)$ maka $\mathrm{H}_{0}$ diterima atau skor mahasiswa setelah diberi tindakan dengan model pembelajaran peer teaching tidak berbeda dengan skor sebelum mahasiswa diberikan perlakuan. Dengan demikian, $\mathrm{H}_{0}$ diterima yaitu tidak adanya perbedaan antara diberikan perlakuan dengan yang tidak mendapatkan perlakuan.

\section{SIMPULAN}

Berdasarkan hasil penelitian yang dilakukan dapat disimpulkan bahwa terdapat perbedaan yang signifikan ketika mahasiswa menggunakan metode konvensional dengan model pembelajaran peer teaching. Ada perbedaan signifikan dari hasil pretest yang dilakukan setelah mendapat pembelajaran konvensional dengan hasil posttest yang dilakukan setelah mendapat model pembelajaran peer teaching. Uji pada dua sisi menggunakan SPSS 16 menunjukkan 0,309 atau probabilitas di atas 0,05 $(0,309>0,05)$ maka $\mathrm{H}_{0}$ diterima atau skor mahasiswa setelah diberi tindakan dengan model pembelajaran peer teaching tidak berbeda dengan skor sebelum mahasiswa diberikan perlakuan.

\section{REFERENCES}

Arikunto, S. (2006). Prosedur Penelitian. Jakarta: PT. Adi Mahasatya

Boud, D., Cohen, R., \& Sampson, J. (1999). Peer learning and assessment. Assessment \& Evaluation in Higher Education, 24(4), 413-426. Retrieved from https://pes.concordia.ca/docs/peer_ learning_and_assessment.pdf 
Evans, D. J. R., \& Cuffe, T. (2009). Near-peer teaching in anatomy: An approach for deeper learning. Anatomical Sciences Education, 2(5), 227-233. Retrieved from https://onlinelibrary.wiley.com/doi /pdf/10.1002/ase.110

Gay, L.R: Mills, E.G and Airasian, P. (2012). Educational Research: Competencies for Analysis and Applications 9th edition. Pearson.

Harper, G. F., \& Maheady, L. (2007). Peer-mediated teaching and students with learning disabilities. Intervention in School and Clinic, 43(2), 101-107. Retrieved fromhttp://citeseerx.ist.psu.edu/vie wdoc/download?doi=10.1.1.1016.1 $925 \&$ rep $=$ rep $1 \&$ type $=$ pdf

Julien, M. (2001). The syntax of complex tenses. Linguistic Review. https://doi.org/10.1515/tlir.18.2.12 5

Kholiani, W., \& Rosyadi, I. (2016). MEDIA PEMBELAJARAN TENSES BAHASA INGGRIS PADA ENGLISH CLUB BERBASIS ADOBE FLASH CS 3. Jurnal Surya Informatika, 2(1).
Retrieved from http://36.78.223.213/ejurnal/index.php/surya_informatika /article/viewFile/27/31

Rees, E. L., Quinn, P. J., Davies, B., \& Fotheringham, V. (2016). How does peer teaching compare to faculty teaching? A systematic review and meta-analysis. Medical Teacher, 38(8), 829-837. Retrieved from http://elib.vums.ac.ir/bitstream/Ha nnan/21780/1/2016 MT Volume 38 Issue 8 August \%2822\%29.pdf

Schrampfer, B. (202AD). Understanding and Using English gammar. Pearson Education. https://doi.org/10.1136/bmj.316.71 $40.1261 \mathrm{~m}$

Vasay, E. T. (2010). The effects of peer teaching in the performance of students in mathematics. $E$ International Scientific Research Journal, 2(2), 161-171. Retrieved fromhttp://citeseerx.ist.psu.edu/vie wdoc/download?doi=10.1.1.682.73 $95 \&$ rep $=$ rep $1 \&$ type $=$ pdf

Verbs and Tenses.pdf. (n.d.). 